\title{
GENETIC PARAMETERS AND PATH ANALYSIS OF TRAITS OF UPLAND COTTON FOR THE BRAZILIAN SEMI-ARID REGION
}

\author{
PARÂMETROS GENÉTICOS E ANÁLISE DE TRILHA DE CARACTERES DE \\ ALGODOEIRO HERBÁCEO PARA REGIÃO DO SEMI-ÁRIDO BRASILEIRO
}

\author{
Damião Ranieri QUEIROZ1; Francisco Jose Correia FARIAS²; \\ José Jaime Vasconcelos CAVALCANTI ${ }^{2}$; Luiz Paulo de CARVALHO ${ }^{2}$; \\ Diogo Gonçalves NEDER ${ }^{3}$; Gérsia Gonçalves de MELO $^{1}$; Djayran Sobral COSTA ${ }^{1}$; \\ Filipe Cavalcanti FARIAS ${ }^{4}$; Paulo Eduardo TEODORO ${ }^{5^{*}}$
}

1. Universidade Federal Rural do Pernambuco (UFRPE), Recife, PE, Brasil; 2. Embrapa Algodão, Campina Grande, PB, Brasil; 3. Universidade Estadual da Paraíba (UEPB), Campina Grande, PB, Brasil; 4. Universidade Federal de Goiás (UFG), Goiânia, GO, Brasil; 5. Universidade Federal de Mato Grosso do Sul (UFMS), Chapadão do Sul, MS, Brasil. eduteodoro@hotmail.com

\begin{abstract}
Upland cotton fiber is one of the most used natural fibers in the production of textile materials worldwide. For this reason, the selection of genotypes that meet the industry's requirements is one of the main goals of cotton breeding programs. This study aimed to estimate the phenotypic and genotypic correlations among fiber traits and identify the direct and indirect effects of these traits on seed cotton yield of upland cotton genotypes in the semi-arid Brazilian Northeast. This study assessed 21 upland cotton genotypes from a complete diallel cross without reciprocals. The design was randomized blocks, with three replications and 21 treatments. The experiment was conducted in the municipality of Patos - PB, in 2015. The statistical analysis consisted of analysis of variance by the $\mathrm{F}$ test, phenotypic and genotypic correlation analysis, and path analysis. The studied materials revealed genetic variability for all traits. Path analysis has shown that the traits fiber elongation, fiber strength, and fiber fineness have a direct positive effect on seed cotton yield.
\end{abstract}

KEYWORDS: Yield. Gossypium hirsutum L.. Fiber length. Micronaire.

\section{INTRODUCTION}

Upland cotton (G. hirsutum L.) is one of the oldest cultivated plants, and therefore, it is important for agriculture (VIDAL NETO; FREIRE, 2013). Among the four species of the genus cultivated for fiber production, Gossypium hirsutum stands out for contributing with over $90 \%$ to the world's fiber production (PENNA, 2009).

Vidal Neto and Freire (2013) state that the main product of the cotton plant is the fiber, which is composed of $94 \%$ of cellulose, marketed from intrinsic and extrinsic physical traits since the final quality of the cotton depends on these traits. According to these authors, intrinsic traits have a genetic control, are influenced by the environment, and are considered technological and quantified by the HVI device (High Volume Instruments). However, extrinsic traits are acquired by external factors, such as harvesting and storage.

Fiber quality improvement of upland cotton is essential to increase the value and competitiveness of cotton fiber. Genetic breeding of fiber quality depends on the exploitation and efficient use of available genetic resources (FARIAS et al. 2016). In this context, cotton breeding programs seek similar objectives, such as improving yield (main trait) and fiber quality (FREIRE et al. 2008).

Statistical genetic methods should be used to assist breeders in selecting more yielding materials regarding the traits of interest. For instance, correlation among traits identifies the association between them, proving to be essential for breeding programs, especially if the selection of a particular trait is hindered by the low heritability (CRUZ et al. 2012). Correlation can be phenotypic, genotypic, or environmental. Phenotypic correlation can be measured directly, but it has genetic and environmental causes. Pleiotropy is the primary cause of genetic correlation; however, two traits with favorable genotypic correlation may generate gains by indirect selection on other traits (CRUZ et al. 2012).

For the cotton crop, several studies have analyzed the associations between fiber traits. Reis et al. (2017) evaluated the phenotypic correlations between the morphological and technological fiber traits of 21 cotton genotypes and observed the influence of intrinsic fiber traits, especially the micronaire index on yield. Farias et al. (2016) observed the influence of resistance, uniformity, and reflectance on the fiber length in 16 upland cotton genotypes. Munir et al. (2016) found a positive 
correlation between fiber length and resistance with seed cotton yield in an intraspecific and interspecific hybrid population. Tang et al. (1996) studied the genotypic and phenotypic correlations of yield components with fiber traits in an $F_{2}$ hybrid population and observed a positive additive genetic correlation of the fiber resistance with boll weight.

However, correlation coefficients do not reflect the exact relative importance of the direct and indirect effects of one variable on another. To circumvent this limitation, path analysis consists of the study of trait effects on the main trait (CRUZ et al., 2012; CRUZ et al. 2014). This work aimed to estimate the phenotypic and genotypic correlations between technological fiber traits and identify the direct and indirect effects of these traits on the yield of upland cotton genotypes for the semi-arid region of the Brazilian Northeast.

\section{MATERIAL AND METHODS}

The experiment was carried out at the Experimental Field of Embrapa Cotton (lat. $7^{\circ} 0^{\prime}$ 40.55" S; long. $37^{\circ} 16^{\prime} 14.80^{\prime \prime} \mathrm{W}$; alt. $243.28 \mathrm{~m}$ asl), in the municipality of Patos - PB, located in the mesoregion of the Sertão of Paraiba, in 2015, under an average rainfall of $495.7 \mathrm{~mm}$ (AESA, 2015) and field irrigation conditions. The Management was performed according to the crop's needs throughout the experiment. Herbadox (Pendimethalin) and Diuron were applied for weed control at preemergence.

This study evaluated 15 upland cotton hybrids $\left(F_{1}\right.$ 's) from a complete balanced diallel cross, without the reciprocal and the six parental genotypes (FM 993, CNPA 04 2080, PSC 355, TAM B 139-17, IAC 26, and TAMCOT CAMD-E), constituting 21 treatments. The experimental design was a complete randomized block, with three replications. The experimental plot consisted of a 5$\mathrm{m}$ row, with a spacing of $1.0 \mathrm{~m}$ between rows and $0.20 \mathrm{~m}$ between plants, useful area of $10 \mathrm{~m}^{2}$, and population density of 50 plants/row. Seeds were manually sown, and thinning was performed at 30 days after sowing (DAS). The first harvest was carried out at 115 DAS, and the second harvest was performed at 141 DAS.

The following traits were evaluated: seed cotton yield $\left(\mathrm{SY}, \mathrm{kg} \cdot \mathrm{ha}^{-1}\right)$, fiber length $(\mathrm{FL}, \mathrm{mm})$, fiber uniformity (FU, \%), short fiber index (SFI, \%), fiber strength (FS, gf tex ${ }^{-1}$ ), fiber elongation (EL, $\%$ ), fiber fineness (FIN), fiber maturity (MAT), degree of reflectance (DR, \%), degree of yellowing (+b), and spinning index (SPI). Technological fiber traits were evaluated using the HVI device (Uster HVI 1000), by collecting 20 bolls $\cdot \operatorname{plot}^{-1}$ as a standard sample.

The analysis of variance was performed by the $\mathrm{F}$ test at 1 and $5 \%$ probability level. The correlation coefficients were estimated using the expressions contained in Cruz et al. (2012). Initially, multicollinearity was diagnosed. The degree of multicollinearity of the singular matrix $\mathrm{X}^{\prime} \mathrm{X}$ was established based on the condition number $(\mathrm{CN})$, which is the ratio between the largest and the smallest eigenvalue of the matrix. If $\mathrm{NC}<100$, multicollinearity is weak and is not a problem for analysis; if $100 \leq \mathrm{NC}<1000$, multicollinearity is considered moderate to strong; and if $\mathrm{NC} \geq 1000$ is severe (CRUZ et al. 2014). Lastly, path analysis was performed considering seed cotton yield as the principal dependent variable and the other variables as explanatory. All analyses were performed with the Genes software (CRUZ et al. 2013).

\section{RESULTS AND DISCUSSION}

Results revealed significant differences at $1 \%$ probability by $\mathrm{F}$ test among the genotypes for all traits studied, indicating genetic variability among them (Table 1). Queiroz et al. (2017a, b) reported similar results. Genotypes showed ideal means for the cotton crop regarding FU, FS, DR, MAT, +b, and SPI (Table 1) (VIDAL NETO; FREIRE, 2013; FONSECA \& SANTANA, 2002). The coefficient of variation ranged from $0.81 \%$ (MAT) to $20.51 \%$ (SY), which corroborates the results found by Farias et al. (2016) and Carvalho et al. (2016).

The genotypic coefficient of determination $\left(\mathrm{H}^{2}\right)$ provides a proportion of the genetic variance present in the total phenotypic variance, estimating the reliability of the phenotypic value as an indicator of breeding value (RAMALHO et al. 2012). All traits had estimates of $\mathrm{H}^{2}$ higher than $70 \%$, except for SY (57.85 \%) and SFI (64.64 \%) (Table 1).

Based on the estimates of phenotypic correlation $\left(r_{f}\right)$ (Table 2), seed cotton yield (SY) showed no significant positive or negative correlation $\left(\mathrm{r}_{\mathrm{f}}\right)$ among fiber traits. However, this variable had a positive and non-significant correlation with reflectance (DR), fineness (FIN), maturity (MAT), degree of yellowing $(+b)$, and fiber strength (FS). Such results agree with those of Tonk et al. (2018). Munir et al. (2016) also found a positive and significant correlation between SY and FS. 
Table 1. Summary of analysis of variance, means, coefficient of variation (CV), genotypic coefficient of determination $\left(\mathrm{H}^{2}\right)$ for the traits: seed cotton yield (SY), fiber length (FL), fiber uniformity (FU), short fiber index (SFI), fiber strength (FS), fiber elongation (EL), fiber fineness (FIN), fiber maturity (MAT), degree of reflectance (DR), degree of yellowing $(+b)$, and spinning index (SPI), Patos - PB.

\begin{tabular}{lllll}
\hline Trait & MS & Means & CV $(\%)$ & $\mathrm{H}^{2}(\%)$ \\
\hline SY $\left(\mathrm{kg} \mathrm{ha}^{-1}\right)$ & $1939769.94^{* *}$ & 4408.23 & 20.51 & 57.85 \\
FL $(\mathrm{mm})$ & $11.51^{* *}$ & 28.71 & 2.77 & 94.48 \\
FU $(\%)$ & $3.46^{* *}$ & 85.31 & 1.14 & 72.26 \\
SFI $(\%)$ & $0.50^{* *}$ & 6.32 & 6.65 & 64.64 \\
FS $\left(\mathrm{gftex}^{-1}\right)$ & $17.57^{* *}$ & 32.62 & 4.46 & 87.91 \\
EL $(\%)$ & $0.98^{* *}$ & 4.78 & 7.61 & 86.55 \\
FIN $(\mathrm{IM})$ & $0.47^{* *}$ & 5.28 & 5.11 & 84.60 \\
MAT $(\%)$ & $0.00^{* *}$ & 0.89 & 0.81 & 83.30 \\
DR $(\%)$ & $4.35^{* *}$ & 81.59 & 0.95 & 86.08 \\
+b & $1.07^{* *}$ & 9.70 & 4.09 & 85.25 \\
SPI & $399642.63^{* *}$ & 2764.06 & 6.73 & 91.32 \\
\hline
\end{tabular}

${ }^{\mathrm{ns}}$ Not significant. * and **Significant at 1 and $5 \%$ probability by $\mathrm{F}$ test, respectively. MS: mean square.

For FL, the traits FU, FS, and SPI showed significant positive estimates $\left(\mathrm{r}_{\mathrm{f}}\right)$, indicating that the selection for FL may result in significant gains for these correlated traits. Hoogerheide et al. (2007) observed a positive and significant correlation between length (FL) and uniformity (FU). Tonk et al. (2018) found a significant and positive phenotypic correlation between FL and FS and FU.

The trait FU showed a significant and positive correlation $\left(\mathrm{r}_{\mathrm{f}}\right)$ with $\mathrm{FS}$ and SPI. Fiber strength (FS) and uniformity (FU) are important traits in the selection of cotton genotypes for fiber quality, and the higher the strength $\left(>28\right.$ gf tex $\left.^{-1}\right)$ and uniformity $(>82 \%)$, the more acceptable are these materials (VIDAL NETO; FREIRE 2013, FONSECA; SANTANA 2002). For the short fiber index (SFI), FS, and SPI had significant and negative $r_{f}$ estimates, indicating a negative correlation between these traits.

The trait FS showed significant and positive correlation $\left(r_{f}\right)$ with SPI. Fiber elongation (EL) was positively correlated with degree of yellowing $(+b)$. Fiber fineness $(F I N)$ had a significant positive $\left(r_{f}\right)$ with $+b$ and negative estimates with SPI. Fiber maturity (MAT) showed negative estimates $\left(\mathrm{r}_{\mathrm{f}}\right)$ with SPI. Degree of reflectance (D) showed negative estimates $\left(r_{f}\right)$ with $+b$, while $+b$, had positive estimates $\left(r_{f}\right)$ for EL and FIN (Table 2). These results are similar to those reported by Beyer et al. (2014) and Zeng and Pettigrew (2015).

For the estimates of genotypic correlation $\left(\mathrm{r}_{\mathrm{g}}\right)($ Table 2 ), no significant differences by $t$-test were observed. For seed cotton yield (SY), the traits FIN and MAT showed the highest positive estimates (0.28 and 0.27), respectively. For FL, the highest positive estimates were observed for SPI, FU, and FS (0.97, 0.85, and 0.69, respectively).

Fiber uniformity (FU) showed a positive correlation with SPI and FS. Short fiber index (SFI) showed high positive correlation with DR. The trait FS obtained high positive correlation with SPI. Fiber fineness (FIN) obtained high correlation estimates with fiber maturity (MAT) and degree of yellowing $(+b)(0.97$ and 0.51 , respectively). MAT showed to be positively correlated with $+b$, and DR showed a positive correlation with SPI. These results are similar to those found by Hoogerheide et al. (2007) for an upland cotton crop.

Falconer (1987) reported that the leading cause of genetic correlation, whether of positive or negative magnitude, is pleiotropy or gene linkage in the control of these traits- the latter has a transitory effect. However, a favorable genetic correlation among two traits implies the possibility of obtaining gains by indirect selection on these traits (CRUZ et al. 2012).

Correlation coefficients are of great importance for the understanding of the association among traits. However, these estimates do not demonstrate the cause and effect relationship between these traits. Path analysis, conversely, allows understanding the performance of these effects on the main trait (CRUZ et al. 2012, CRUZ et al. 2014). 
Table 2. Phenotypic and genotypic correlations among the traits seed cotton yield (SY), fiber length (FL), fiber uniformity (FU), short fiber index (SFI), fiber strength (FS), fiber elongation (EL), fiber fineness (FIN), fiber maturity (MAT), degree of reflectance (DR), degree of yellowing (+b) and spinning index (SPI).

\begin{tabular}{|c|c|c|c|c|c|c|c|c|c|c|c|}
\hline & Correlation & $\mathrm{FL}$ & $\mathrm{FU}$ & SFI & $\mathrm{FS}$ & EL & FIN & MAT & $\mathrm{DR}$ & $+\mathrm{b}$ & SPI \\
\hline \multirow{2}{*}{ SY } & $\mathrm{r}_{\mathrm{f}}$ & -0.06 & -0.04 & -0.11 & 0.07 & -0.09 & 0.14 & 0.13 & 0.15 & 0.11 & -0.03 \\
\hline & $r_{g}$ & -0.10 & -0.23 & -0.06 & 0.07 & -0.04 & 0.28 & 0.27 & 0.10 & 0.18 & -0.11 \\
\hline \multirow{2}{*}{ FL } & $\mathrm{r}_{\mathrm{f}}$ & 1 & $0.75^{* *}$ & $-0.47 *$ & $0.64 * *$ & -0.19 & $-0.73 * *$ & $-0.59 * *$ & 0.28 & -0.39 & $0.94 * *$ \\
\hline & $r_{g}$ & 1 & 0.85 & -0.53 & 0.69 & -0.19 & -0.82 & -0.67 & 0.30 & -0.42 & 0.97 \\
\hline \multirow{2}{*}{$\mathrm{FU}$} & $r_{f}$ & & 1 & $-0.77 * *$ & $0.68 * *$ & 0.17 & -0.36 & -0.31 & -0.02 & -0.08 & $0.86 * *$ \\
\hline & $r_{g}$ & & 1 & -0.88 & 0.79 & 0.29 & -0.40 & -0.39 & -0.05 & -0.05 & 0.90 \\
\hline \multirow{2}{*}{ SFI } & $r_{f}$ & & & 1 & $-0.74 * *$ & -0.36 & 0.03 & 0.01 & 0.29 & -0.32 & $-0.65 * *$ \\
\hline & $r_{g}$ & & & 1 & -0.94 & -0.49 & 0.03 & -0.06 & 0.45 & -0.48 & -0.74 \\
\hline \multirow{2}{*}{ FS } & $\mathrm{r}_{\mathrm{f}}$ & & & & 1 & 0.09 & -0.24 & -0.12 & -0.002 & -0.02 & $0.82 * *$ \\
\hline & $r_{g}$ & & & & 1 & 0.07 & -0.26 & -0.15 & -0.02 & -0.00 & 0.84 \\
\hline \multirow{2}{*}{ EL } & $r_{f}$ & & & & & 1 & 0.06 & -0.21 & -0.30 & $0.47^{*}$ & 0.00 \\
\hline & $r_{g}$ & & & & & 1 & 0.05 & -0.20 & -0.32 & 0.55 & 0.03 \\
\hline \multirow{2}{*}{ FIN } & $r_{f}$ & & & & & & 1 & 0.94 & -0.33 & $0.44^{*}$ & $-0.66 * *$ \\
\hline & $r_{g}$ & & & & & & 1 & 0.97 & -0.36 & 0.51 & -0.68 \\
\hline \multirow{2}{*}{ MAT } & $r_{f}$ & & & & & & & 1 & -0.24 & 0.31 & $-0.54^{*}$ \\
\hline & $r_{g}$ & & & & & & & 1 & -0.25 & 0.38 & -0.59 \\
\hline \multirow{2}{*}{ DR } & $r_{f}$ & & & & & & & & 1 & $-0.75 * *$ & 0.15 \\
\hline & $r_{g}$ & & & & & & & & 1 & -0.82 & 0.15 \\
\hline \multirow{2}{*}{$+b$} & $\mathrm{r}_{\mathrm{f}}$ & & & & & & & & & 1 & -0.25 \\
\hline & $\mathrm{r}_{\mathrm{g}}$ & & & & & & & & & 1 & -0.26 \\
\hline
\end{tabular}

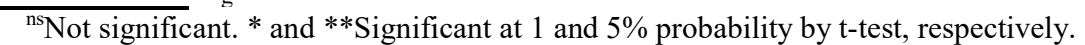


To perform the path analysis, the $\mathrm{X}^{\prime} \mathrm{X}$ matrix must be well-conditioned. Multicollinearity problems can make the singular matrix (noninvertible matrix), making unreliable estimates. One of the alternatives to avoid such problems is the elimination of variables inducing these results by means of the multicollinearity diagnosis (CRUZ et al. 2014). Multicollinearity diagnosis indicated that only SPI had $\mathrm{CN}>100$,which is an issue for path analysis. For this reason, this variable was eliminated, and path analysis was performed using a constant $\mathrm{k}=0.05$ in the diagonal of the phenotypic correlation matrix.

From the path analysis estimates, the variables that obtained the highest positive direct effects associated with a positive phenotypic correlation with the main trait (SY) were FIN (0.34), DR (0.51), and +b (0.40) (Table 3).

Table 3. Estimates of direct and indirect effects of the traits: fiber length (FL), fiber uniformity (FU), short fiber index (SFI), fiber strength (FS), fiber elongation (EL), fiber fineness (FIN), fiber maturity (MAT), degree of reflectance (DR), degree of yellowing (+b), and spinning index (SPI) on seed cotton yield (SY).

\begin{tabular}{lllllllllll}
\hline Effect & FL & FU & SFI & FS & EL & FIN & MAT & DR & $+\mathrm{b}$ & SPI \\
\hline Direct on SY & -0.34 & -0.06 & -0.41 & 0.11 & -0.44 & 0.34 & -0.48 & 0.51 & 0.40 & -0.02 \\
Indirect via FL & - & -0.26 & 0.16 & -0.21 & 0.06 & 0.25 & 0.20 & -0.10 & 0.13 & -0.32 \\
Indirect via FU & -0.05 & - & 0.05 & -0.04 & -0.01 & 0.02 & 0.02 & 0.00 & 0.00 & -0.06 \\
Indirect via SFI & 0.19 & 0.31 & - & 0.31 & 0.15 & -0.01 & 0.00 & -0.12 & 0.13 & 0.27 \\
Indirect via FS & 0.07 & 0.07 & -0.08 & - & 0.01 & -0.03 & -0.01 & 0.00 & 0.00 & 0.09 \\
Indirect via EL & 0.08 & -0.07 & 0.16 & -0.04 & - & -0.03 & 0.09 & 0.13 & -0.20 & 0.00 \\
Indirect via FIN & -0.25 & -0.12 & 0.01 & -0.08 & 0.02 & - & 0.32 & -0.11 & 0.15 & -0.22 \\
Indirect via MAT & 0.28 & 0.15 & 0.00 & 0.06 & 0.10 & -0.44 & - & 0.11 & -0.15 & 0.25 \\
Indirect via DR & 0.14 & -0.01 & 0.15 & 0.00 & -0.15 & -0.17 & -0.12 & - & -0.38 & 0.08 \\
Indirect via +b & -0.16 & -0.03 & -0.12 & -0.01 & 0.19 & 0.17 & 0.12 & -0.30 & - & -0.10 \\
Indirect via SPI & -0.01 & -0.01 & 0.01 & -0.01 & 0.00 & 0.01 & 0.01 & 0.00 & 0.00 & \\
\hline Coefficient of determination & & & & & & & & 0.88 & \\
Residual effect & & & & & & & & & 0.22 & \\
\hline
\end{tabular}

High magnitude negative direct effects were observed for FL (-0.34), SFI (-0.41), EL (-0.44), and MAT (-0.48). Similar results were reported by Hoogerheide et al. (2007), who verified through path analysis that FIN had the highest positive direct effect (0.54) on SY, and FL had negative direct effect on SY (-0.20). Considering that SY is a quantitative trait governed by several genes and highly influenced by the environment, path analysis was able to explain $88 \%$ of the variation of this trait. Also, the cause and effect associations identified in this work can be used to construct selection indices for multi-trait selection in segregating populations.

\section{CONCLUSIONS}

Results revealed variability to be explored in the population for the selection of upland cotton genotypes for the semi-arid region of the Brazilian Northeast.

The traits spinning index, fiber length, fiber uniformity, and fiber strength showed high correlation among each other, indicating a possibility of gains by the simultaneous selection for these traits.

A low phenotypic and genotypic correlation was observed among seed cotton yield and fiber traits, confirming an issue for the simultaneous selection based on these traits.

Fiber fineness, degree of reflectance, and degree of yellowing had the greatest direct effect on the main variable (SY).

RESUMO: A fibra do algodoeiro herbáceo é uma das fibras naturais mais utilizadas na produção de materiais têxteis no mundo. Portanto, a seleção de genótipos que atendam às exigências desta indústria é um dos principais objetivos dos programas de melhoramento do algodoeiro. $\mathrm{O}$ objetivo deste estudo foi estimar as correlações fenotípicas e genotípicas entre as características tecnológicas da fibra e identificar os efeitos diretos e indiretos destas características sobre a produtividade de algodão em caroço de genótipos de algodoeiro 
herbáceo no semiárido nordestino. Foram avaliados 21 genótipos de algodoeiro herbáceo provenientes de um cruzamento dialélico completo sem os recíprocos. O delineamento utilizado foi blocos completos ao acaso, com três repetições. O experimento foi conduzido no município de Patos - PB, em 2015. As análises estatísticas consistiram de análise de variância pelo teste $\mathrm{F}$, análise de correlação fenotípica e genotípica e análise de trilha. Todas as características apresentaram variabilidade genética entre os genótipos estudados. A correlação fenotípica foi positiva entre CSP, COMP, UNF e RES. Foram observados efeitos indiretos de ALON, COMP e FIN sobre PROD, por meio das variáveis FIN, RD e $+b$.

PALAVRAS-CHAVE: Produtividade. Gossypium hirsutum L.. Comprimento da fibra. Micronaire.

\section{REFERENCES}

AGÊNCIA EXECUTIVA DE GESTÃO DAS ÁGUAS DO ESTADO DA PARAÍBA (AESA). Chuvas acumuladas no ano 2015. Disponível em: $<$ http://site2.aesa.pb.gov.br/aesa/monitoramentoPluviometria.do $>$. Acesso em: 13 Mar. 2018. (VERIFICAR CITAÇÃO NO TEXTO)

CARVALHO, L. P. D.; FARIAS, F. J. C.; MORELLO, C. D. L.; TEODORO, P. E. Selection of cotton genotypes for greater length of fibers. Crop Breeding and Applied Biotechnology, Viçosa, v. 16, n. 4, 340347, 2016. https://doi.org/10.1590/1984-70332016v16n4n50

BEYER, B. M.; SMITH, C. W.; PERCY, R.; HAGUE, S.; HEQUET, E. F. Test Cross Evaluation of Upland Cotton Accessions for Selected Fiber Properties. Crop Science, Madson, v. 54, p. 60-67, 2014. https://doi.org/10.2135/cropsci2013.06.0374

\section{CRUZ, C. D.; REGAZZI, A. J.; CARNEIRO, P. C. S. Modelos biométricos aplicados ao melhoramento} genético. Viçosa: UFV, 2012.

CRUZ, C. D. GENES - a software package for analysis in experimental statistic and quantitative genetics. Acta Scientiarum. Agronomy, Maringá, v. 35, n. 3, p. 271-276, 2013. https://doi.org/10.4025/actasciagron.v35i3.21251

CRUZ, C. D.; CARNEIRO, P. C. S.; REGAZZI, A. J. Modelos biométricos aplicados ao melhoramento genético. Viçosa: UFV, 2014.

FALCONER, D. S. Introdução à genética quantitativa. Viçosa: UFV, 1987.

FARIAS, J. C. F.; CARVALHO, L. P.; SILVA FILHO, J. L.; TEODORO, P. E. Correlations and path analysis among agonomic and technological traits of upland cotton. Genetics and Molecular Research, Ribeirão Preto, v. 15, n. 3, p. 1-8, 2016. https://doi.org/10.4238/gmr.15038239

FONSECA, R. G.; SANTANA, J. C. F. Resultados de ensaio HVI e suas interpretações (ASTM D-4605). Campina Grande: Embrapa Algodão, 2002. (Circular Técnica, 66).

FREIRE, E. C.; MORELlO, C. D. L.; FARIAS, F. J. C.; SILVA FILHO, J. D.; VIDAL NETO, F. D. C.; PEDROSA, M. B.; ANDRADE, F. D. Objetivos e métodos usados nos programas de melhoramento do algodão. In: BELTRÃO, N. E. M.; AZEVEDO, D. M. P. O agronegócio do algodão no Brasil. Brasília: Embrapa, 2008. p. 299-324.

HOOGERHEIDE, E. S. S.; VENCOVSKY, R.; FARIAS, F. J. C.; FREIRE, E. C.; ARANTES, E. M. Correlações e análise de trilha de caracteres tecnológicos e a produtividade de fibra de algodão. Pesquisa Agropecuária Brasileira, Brasília, v. 42, n. 10, p. 1401-1405, 2007. https://doi.org/10.1590/S0100204X2007001000005 
MUNIR, S.; HUSSAIN, S. B.; MANZOOR, H.; QUERESHI, M. K.; ZUBAIR, M.; NOUMAN, W.; MANZOOR, S. A. Heterosis and correlations in interspecific and intraspecific hybrids of cotton. Genetics and Molecular Research, Ribeirão Preto, v. 15, n. 2, p. 1-13, 2016. https://doi.org/10.4238/gmr.15028083

PENNA, J. C. V. Hibridação em algodão. In: BORÉM, A. Hibridação artificial de plantas. Viçosa: UFV, 2009. p. 67-89.

QUEIROZ, D. R.; FARIAS, F. J. C.; CARVALHO, L. P.; NEDER, D.; SOUZA, L.; FARIAS, F.; TEODORO, P. E. Diallel analysis for agronomic traits in upland cotton in semi-arid zones in Brazil. Genetics and

Molecular Research, Ribeirão Preto, v. 16, n. 3, p. 1-8, 2017a. https://doi.org/10.4238/gmr16039677

QUEIROZ, D. R.; FARIAS, F. J. C.; CAVALCANTI, J.J.V.; CARVALHO, L.P.; NEDER, D.; SOUZA, L.; FARIAS, F.; TEODORO, P. E. Diallel analysis for technological traits in upland cotton. Genetics and Molecular Research, v. 16, n. 3, p. 1-8, 2017b. https://doi.org/10.4238/gmr16039727

RAMALHO, M. P.; ABREU, A. D. F.; SANTOS, J. D.; NUNES, J. A. R. Aplicações da genética quantitativa no melhoramento de plantas autógamas. Lavras: UFLA, 2012.

REIS, M. C.; CARDOSO, D. B. O.; SILVA JUNIOR, E. G.; GOMES, B. C.; PEREIRA, L. G. T.; GOMES, D. A.; SOUSA, L. B. Correlation among traits as criterion of cotton genotypes indirect selection. Genetics and Molecular Research, v. 16, n. 3, p. 1-9, 2017.

VIDAL NETO, F. C.; FREIRE, E. C. Melhoramento genético do algodoeiro. In: VIDAL NETO, F. C.; CAVALCANTI, J. J. V. Melhoramento genético de plantas no nordeste. Brasília: Embrapa, 2013. p. 49-83.

TANG, B.; JENKINS, J. N.; WATSON, C. E.; MCCARTY, J. C.; CREECH, R. G. Evaluation of genetic variances, heritabilities, and correlations for yield and fiber traits among cotton $\mathrm{F}_{2}$ hybrid populations. Euphytica, Dordrecht, v. 91, p. 315-322, 1996. https://doi.org/10.1007/BF00033093

TONK, F. A.; ISTIPLILER, D.; TOSUN, M.; ILKER, E.; ÇIVI, G. Correlation and path analysis in yield and quality traits in $\mathrm{F}_{3}$ and $\mathrm{F}_{4}$ generations of Carmen $\mathrm{x}$ devetutyu-176. The Journal of Animal \& Plant Sciences, New York, v. 28, n. 1, p. 107-112, 2018.

ZENG L.; PETTIGREW, W. T. Combining ability, heritability, and genotypic correlations for lint yield and fiber quality of Upland cotton in delayed planting. Field Crops Research, Amsterdão, v. 171, p. 176-183, 2015. https://doi.org/10.1016/j.fcr.2014.10.004 